\title{
MEDIA EDUCATION IN POLAND - NEEDS VERSUS REALITY
}

\author{
Anna BROSCH*, University of Silesia in Katowice, Poland
}

Received: 21. 6. 2017 / Accepted: 28. 11. 2017

Type of article: original research

DOI: $10.5507 /$ jtie. 2017.030

Abstract: Media education should strive to shape an attitude of active creativity which ought to become a desired alternative for the passive way of experiencing the media. Therefore media education is a precious form of education, however, it is still imperfect and requires constructive changes. Meanwhile, in Polish education system there is no clear definition of media literacy, of what should be called media education and to what objectives that education should lead. The main goal of the research was the overview of the history of media education in Polish educational system and the practices for developing media education and media literacy in Poland, as well the teachers 'attitudes towards media education and ways of developing media literacy among pupils. In order to collect empirical material, a survey was conducted among teachers from the Silesian Voivodship. The study involved 87 teachers. As well the analysis of content was used concerning strategic international and national documents, encompassing the points mentioned above. The best way to characterize the state of media education in Poland is to say that the policy makers, people who decide about its popularization in schools, prefer to be conservative about the whole concept.

Key words: media education, media literacy, core curriculum, teachers.

\section{MEDIÁLNÍ VÝCHOVA V POLSKU - POTŘEBY VERSUS REALITA}

Abstrakt: Mediální výchova by měla usilovat o rozvoj aktivně-tvořivého přistupu, který by se mél stát vhodnou alternativou k pasivnímu způsobu setkávání se s médii. Je proto významnou součástí vzdělávání, kterou je nicméně stále nezbytné zdokonalovat. Prozatím v polském vzdělávacím systému neexistuje jasná definice mediální gramotnosti, co by mělo být nazýváno mediální výchovou a jaké cíle by měla sledovat. V článku je uveden přehled historie mediální výchovy $v$ polském vzdělávacím systému a praxe rozvoje mediálni výchovy, vč. mediálni gramotnosti. Výzkum se zaměruje na postoje učitelů k mediální výchově a způsoby rozvoje mediálni gramotnosti žáků.

Klíčová slova: mediální výchova, mediální gramotnost, klíčové kurikulum, učitel.

*Autor pro korespondenci: anna.brosch@us.edu.pl 


\section{Introduction}

In a dynamically changing reality, evolution touches both media and the spheres of life that are influenced by new technologies and their development. Moreover, through proper actions it should form positive attitudes towards the media. One of such attitudes is without a doubt the critical approach that assumes the knowledge of the main mechanisms of the media, emotional distance towards their proposed coverage, and researching the desired information in numerous sources and making comparison, that is estimating their credibility (Nowakowska-Buryła, 2003).

The global adoption of ICT into education has often been premised on the potential of the new technological tools to revolutionize an outmoded educational system and prepare students for the information age. However, a number of studies have shown that the successful implementation of educational technologies depends largely on the attitudes of educators, who eventually determine how they are used in the classroom (Koohang, 1989). This suggests that studies at the early stages of technology implementation should focus on the end-users' attitudes toward technology. Moreover recent research have shown, that teachers who have positive attitudes toward technology feel more comfortable with using it and usually incorporate it into their teaching (Kersaint, Horton, Stohl, and Garofalo, 2003). As Baylor and Ritchie (2002) state, "regardless of the amount of technology and its sophistication, technology will not be used unless faculty members have the skills, knowledge and attitudes necessary to infuse it into the curriculum" (p. 398). That is, teachers should become effective agents to be able to make use of technology in the classroom. Ultimately, teachers are the most important agents of change within the classroom arena.

On the other hand, media education in Poland has not become compulsory at schools yet. Although media literacy education was introduced to schools of primary and junior high level in 1999 as part of the core curriculum as so-called "educational path", but the implementation of the curriculum proved inconsistent and the media education programme was given up in 2008. The result of this is the duality of media education in current core curriculum: on the one hand, it is not mentioned in the general education goals, but on the other, it is noticeable in all of the aspects of the core curriculum. However, presenting the fragmentary information instead of the process of building up knowledge, as well as not having the ability of critical interpretation, cannot lead to forming media literacy - the only real goal in such a situation is to simply provide the pupils with basic skills as media users. Moreover, treating media and informational education jointly is reducing media education simply to a matter of technical training (Siemieniecki, 2002). However, there is a noticeably growing interest in media education, the result of which is a series of postulates and endeavours taken up by the academic communities and organizations interested in the issue.

\section{The history of media education in Poland}

In the nearly 25 years the Polish educational system was reformed, and therefore the core curriculum at all educational levels was modified. At present, the educational system was defined by the Act on Education of 1991 (Ustawa o systemie oświaty z dnia 7 września 1991) and the structure of educational institutions was radically reformed in 1999.

The relevance of media education in Poland was explicitly recognized in the first decade of the 1990's in connection with significant political and economic changes. Polish 
media educators began to actively implement foreign, and first of all, the European experience. From now on, the problems of media competence development got on the agenda.

Seven years after the political turnover of 1989, one of the Polish pioneers of media education Wacław Strykowski called for general and curriculum based media education as required by the new social order, to support (and enhance) the educational process and to keep the youth secure, both in their choice and use of media. He pointed to three main goals to be accomplished:

- $\quad$ use of media for intellectual and professional ends

- developing a critical understanding of media messages as means of value transmission and attitude formation

- $\quad$ appropriate use of media for entertainment (Strykowski, 1997).

Since 1998 media education in Poland was integrated with the humanities, the scope of published media education programs, training manuals, monographs and articles extended. It was then understood as media pedagogy, education through media, but mostly education for media (Drzewiecki 2010b, p. 35). At the same time, one could often hear in the society the opinions underlying the necessity of introducing autonomous media studies or courses as well.

Media education movement spread both at universities and at schools. As a result media literacy education was introduced to schools of primary and junior high level in 1999 as part of the core curriculum. Its aims focused on developing competences of critical media content reception and responsible media use.

In 2005, the Polish Film Institute (PFI) was established. It carried out a number of projects connected with media education. Thus packets with 50 DVDs containing games, documentary and animation films were sent to 14,000 Polish schools. Each of them was selected by experts according to their training programs (Lipszyc, 2012).

In the following decade, this first programme of media education was criticised and the problem was soon taken up by the Polish media regulatory authority - the National Broadcasting Council (KRRiT: Krajowa Rada Radiofonii i Telewizji), which began to supervise the development of media education at national level. The ideas concerning a complex development of media education in Poland including the appropriate training of teachers and the involvement of public organizations, libraries and local authorities in media education were put forward. Therefore KRRiT was an extremely important Polish entity interested in institutional activities for promoting media education. Back in 2000, KRRiT commissioned a report on the state of media education in Poland, written by scholars from the Institute of the Audio-Visual Arts of the Jagiellonian University under the supervision of professor Wiesław Godzic. The authors of the study emphasized that the importance of media education was being downplayed and neglected, and that the consequence of that was a badly written core curriculum, decision-making disarray, the lack of contemporary role models and the lack of proper teaching resources (Godzic, 2000). That same year KRRiT organized a conference for scholars "Media Education - the Need and the Challenge for the Future", which started a debate on the issue of media education.

In the years 2003-2008 media education was more of a social movement than a policy of the government. Numerous initiatives grew out of European-based programmes, for example Media Programme or Safer Internet. Websites devoted to education for the media 
were set up, e.g. EdukacjaMedialna.pl, Edunews.pl. However, there was no coordination at the national level of these initiatives, neither was media education extensively promoted (Drzewiecki 2010b, p. 38).

The entry of Poland into the European Union enabled Polish media educators to rely on such solutions as the European Commission Communication on media literacy of December 2007 (COM(2007)833 - A European approach to media literacy in the digital environment) invited member state governments to coordinate and regulate the activities of all parties involved in media literacy development.

Therefore, the Polish National Broadcasting Council initiated a series of conferences which gathered media education experts. On May 7th, 2008 the first session of the Media Education Forum commenced, with numerous representatives of culture, education, work and science sectors in attendance, as well as media representatives, members of various colleges and universities, social institutions and associations (Media Education in KRRiT). Since then the Forum gathered, during its plenary meetings, distinguished experts in the field who have been promoting for many years the need to introduce media education in Poland. Each of those meetings saw a number of lectures on specific issues and problems, leading to some heated debates. Participants of the Media Education Forum could attend the speeches by prof. Bronisław Siemieniecki from the Nicolaus Copernicus University in Toruń, dr Piotr Drzewiecki from the Cardinal Stefan Wyszyński University in Warsaw, and dr Lucyna Kirwil from the University of Social Sciences and Humanities. A team of experts on media education was put together under KRRiT. In 2002 its members met with Tomasz Goban-Klas, at that time the secretary in the Ministry of National Education and Sports (MENiS). MENiS began its preparations to introduce the new subject to schools. Unfortunately, after 2003 the involvement of KRRiT in promoting media education became weaker, and it finally began to resemble something more akin to a social movement. The activities linked to introducing media education as a separate school subject were also suspended. The breakthrough came at the end of 2007 when the European Union's new audiovisual directive (Directive 2007/65/WE) called the membership countries to cope with the issue of media education. However, all the work put into writing the new core curriculum did not meet expectations because representatives of the Ministry of National Education raised the issue of the lack of professionally trained didactic staff. Despite the postulates of media pedagogues and media experts, expressed openly during numerous events, including the sessions of the Media Education Forum organized by the National Broadcasting Council in the years 2008-2010, it was not possible to implement "media education" subject in Polish schools (Drzewiecki, 2010b).

Also the European Parliament resolution of 16 December 2008 on media literacy in a digital world (2008/2129(INI)) urged the relevant member state institutions to make media education an important and relatively independent component of education. In this connection it was asserted that media education should be part of lifelong learning and should involve not only preschool children, school and university students, the under-age audience as a whole but also teachers, parents, adults, pensioners.

In spite of these initiatives on the part of the Council as well as various nongovernmental organisations, the Ministry of National Education decided against the extensive presence of media education as an integral part of school programmes. The new core curriculum, issued in 2009 , drastically limited media education by restricting it 
severely. Significantly, the integrity of the initial media education programme was effectively eliminated, with merely some aspects remaining in teaching selected school subjects.

In reality, the teaching of media competences was restricted to IT skills and reception of ICT messages, in other words, passive skills rather than active and creative use of media (Boroń, 2010).

Therefore, in 2012 the Polish Association of Media Education was created at the initiative of academics as well as practitioners concerned with media education. Its main aim is to spread knowledge of media and media education, and to support research in this area. The organisation is headed by prof. Agnieszka Ogonowska of the Pedagogical University in Cracow.

Media education in Poland has not become compulsory at schools yet. The Ministry of Education agreed with the general conceptions about the necessity of media education but would not introduce special courses in media culture thus having integrated the media education component in different school subjects. At the same time, media studies are available in the form of autonomous elective courses.

\section{Media education in international and national strategic documents}

The documents of European Union institutions have for many years now formulated priorities and guidelines for its member states, including Poland. According to them media literacy is increasingly becoming an important component of European and national policy agendas in the media and communication sectors. The most important ones for media education policies have been as follows:

1. Recommendation of the European Parliament and of the Council of 18 December 2006 on Key Competences for Lifelong Learning (2006/962/EC) - defined the digital competences, which included the ability to search, collect and process information and use it in a critical and systematic way, assessing relevance and distinguishing the real from the virtual while recognising the links.

2. Communication from the Commission to the European Parliament, the Council, the European Economic and Social Committee and the Committee of the Regions - A European approach to media literacy in the digital environment (12 December 2007, COM(2007)833) - underlines the importance of media literacy and image education initiatives in order to access European audiovisual works and to enhance Europe's cinematographic and audiovisual heritage.

3. European Parliament Resolution of 16 December 2008 on Media Literacy in a Digital World 2008/2129(INI) - indicates that media education is essential to achieving a high level of media literacy, which is an important part of political education.

4. Social Capital Development Strategy in Poland 2020 (2013) - focuses on ICT in education and in non-formal education, development of digital competences of the groups at risk of social exclusion, adapting the offer of the training courses to the needs of the labour market as regards the fundamental ICT competences.

The development of information society in Poland is being monitored by the Ministry. Its recent report is an example: Information society in numbers (Szymanek, 2013) summarizes the current state of affairs with respect to Poles' digital competences, Internet access, the use of new digital tools for social and educational ends. The coherent 
programme of the development of information society was indicated in the Long-term National Development Strategy. Poland 2030. The third wave of modernity (2013), adopted by the Council of Ministers at the beginning of the year 2013. The document defined the fundamental courses of interventions, including developing digital competences of teaching personnel (e.g. teachers, employees of other educational and cultural institutions, employees of NGOs) and implementing common digital education as well as establishing modern infrastructure and educational resources.

\section{The international and national initiatives concerning media education}

Due to lack of indication in Polish core curriculum concerning media education there are series of initiatives to change this situation. Problems associated with media education has become a subject of discussion of many scientific conferences. Among them are media education conferences organized mostly by state institutions, universities and academics. This is a great opportunity to debate over the importance of media and information literacy for social, economic and cultural development and also to share experiences concerning research on the state of media and information literacy. The most popular conferences organised each year are listed below:

1. Polish Research Symposium "People - Media - Education" organized from 1991 by Pedagogical University of Cracow, Department of Educational Media and Technology.

2. International Conference on Media Education organized from 1997 by Adam Mickiewicz University in Poznan, Department of Education Technology.

3. International Conference on "Communication - Media - Language - Education" organized from 2002 by Civitas Christiana in Torun.

4. National Conference "Computer Science in Education" organized from 2003 by Nicolaus Copernicus University in Torun, Faculty of Mathematics and Computer Science.

5. Media Education Forum organized from 2008 by National Broadcasting Council.

6. The Media Education Congress organized from 2014 by The Polish Association of Media Literacy.

The primary goal and mission of theses conferences is to encourage and promote research in the theory and practice of media education at the school, college and university levels of education. Members focus on media education theory and practices and research relating to 'knowledge societies' and critical analysis of strategies and policies.

Additionally, media education is a wide discussed during single event conferences organized by Polish universities and state institutions such as the Polish Film Institute or Center for Citizenship Education. Although The issue of the media education is raised more and more often, the results of this debate hardly influenced the shape of education in Poland.

Although media and information education has for years been the subject of academic debate and one of the priorities of the state, present in documents such as Social Capital Development Strategy 2020, there is still lack of answers to the question of what the media and information literacy is, what is the scope of its content and what specific skills should be developed. Therefore, the Modern Poland Foundation in cooperation with media and information literacy experts prepared Media and Information Literacy Competences Catalogue. It was approved by the Polish National Commission for UNESCO as a 
significant input into the Information For All international program. The first version of this catalogue was published in May 2012, as part of the Digital Future programme (Cyfrowa przyszlość: Katalog kompetencji medialnych i informacyjnych), and includes topics ranging from information literacy, media discourses and internet safety to economic, ethic and legal aspects of media competence. The competences catalogue is a tool that will allow for the construction of a comprehensive and coherent set of teaching materials for media and information education at different educational stages in the field of lifelong learning. The catalogue lists the following eight thematic areas in which competences are to be considered:

1. Use of information

2. Relations in the media environment

3. Language of media

4. Creative use of media

5. Ethics and values in communications and media

6. Safety in communications and media

7. Law in communications and media

8. Economic aspects of media functioning (Cyfrowa przyszlość: Katalog kompetencji medialnych i informacyjnych, 2012, pp. 12-23).

The Catalogue is based on the structure of a pyramid. It assumes that the person entering a given level of education already has the skills of the previous one, for example high junior school student has already mastered the knowledge and skills suggested for the primary school level in grades 4-6. Thus it was possible to focus only on new competences, characteristic for a given level. It should be also highlighted that the catalogue indicates the competences of students leaving school of a certain level, for example, in the category of high school we put the competences of a student leaving the 3rd, final grade. In 2014 was published a reviewed version of the Catalogue: "Media, information and digital competences catalogue" (2014).

\section{Method and sample}

Given the importance of teachers' attitudes the purpose of this study was therefore to determine teachers' attitudes toward ICT in Polish education according to four aspects: general attitudes towards media, media as educational tools, the assessment of their own digital competences and media access. According to the Ministry of Administration and Digitalization (Szymanek, 2013, p. 14) digital competences are defined as ,a set of information competences covering the ability to search for information, interpret it and to evaluate its credibility and suitability as well as the IT competences, which include the skills of using a computer and other electronic devices, handling the Internet as well as the use of various types of applications and software, and creating digital content". Generally speaking, digital competences include the skills related to the correct use of hardware, software and the Internet. Krumsvik (2011) defined teachers' digital competence as "the teacher's proficiency in using ICT in a professional context with good pedagogic-didactic judgment and his or her awareness of its implications for learning strategies". According to him, there is a double dimension in teachers' competence: they are role models for pupils' subject use of ICT and they must make educational decisions about how ICT may enhance their learning possibilities, in addition to using ICT for personal purposes. Therefore, presented research focused on teachers' basic information and communication 
technology (ICT) skills including basic computer operation and issues, use of application software, use of the internet resources and use of peripheral ICT equipment. The level of digital competences was defined according the standards established by UNESCO in 2008 and reformulated in the year 2011.

In order to collect empirical material, in March 2017 a survey was conducted among teachers from the Silesian Voivodship in Poland. The study involved 87 teachers from primary and high junior schools. More specifically, the study investigated the following questions:

1. What are the attitudes of teachers in Poland towards using media in education?

2. What are the teachers' perceptions of media attributes?

3. How the teachers rate their level of digital competences?

4. How the teachers assess the access to the media?

Participants were asked to respond to 30, Likert-type statements dealing with their attitudes towards media. The items were designed to measure the general attitudes towards the media (items 1-10), educational potential of the media (items 11-20), and digital competences (items 21-30). The teachers' attitudes and competences were represented by a mean score on a 4-point scale, where 4 (Agree) represents the maximum score of the scale and 1 (Disagree) represents the minimum score.

\section{Results and discussion}

As Table 1 illustrates, teachers' overall attitudes towards media were positive with an overall mean score of 3.23 ( $\mathrm{SD}=0.74)$. Over eighty percent of the respondents had positive attitudes towards media, including highly positive $(41.38 \%)$ and positive $(40.23 \%)$. The respondents reported that they had no apprehension of digital media and use them permanently in daily life. Concerning the educational potential of the media, most of the respondents agreed (34.48\%) and rather agreed (39.08\%) that new technologies save time and effort, motivate students to do more study, enhance students' learning, are fast and efficient means of getting information, must be used in all subject matters, make schools a better place, are worth the time spent on learning them, are needed in the classroom, and generally do more good than harm.

\begin{tabular}{|l|c|c|c|c|c|c|}
\hline \multirow{2}{*}{ Scale } & \multicolumn{4}{c|}{ Percent (\%) } & \multirow{2}{*}{ Mean } & \multirow{2}{*}{ SD } \\
\cline { 2 - 7 } & A & RA & RD & D & & \\
\hline General attitudes towards the media & 41.38 & 40.23 & 18.39 & 0.00 & 3.23 & 0.74 \\
\hline Educational potential of the media & 34.48 & 39.08 & 19.54 & 6.90 & 3.01 & 0.90 \\
\hline Digital competences & 21.84 & 31.03 & 28.74 & 18.39 & 2.56 & 1.03 \\
\hline
\end{tabular}

$\mathrm{A}$ - agree (4); RA - rather agree (3); RD - rather disagree (2); D - disagree (1).

\section{Tab. 1: Distribution of mean scores of the teachers attitudes.}

In general, more than half of the respondents highly rated their media competences, including moderate $(31.03 \%)$ and high level $(21.84 \%)$ of digital competence. However, a significant part of the respondents had no (18.39\%) or had low level of $(28.74 \%)$ digital competence within most of the computer functions needed by educators. The main problems with media usage were connected with software installation including installation and usage of application, telecommunication resources, basic troubleshooting, 
graphic applications, educational software evaluation, organization tools, virus removal and even with preparing professional multimedia presentation.

Regarding the media access especially at schools, the teachers admitted that the main problem is inadequate equipment in media devices. Although computers, multimedia projectors and withboards have become more available, but it is still not enough. Moreover, the respondents emphasised that in most of schools in Poland the usage of smartphones and tablets by students is forbidden. Although they appreciate the potential of smartphone with its camera, dictaphone and many application, but as they stated, the banning of smartphones can avoid many problems such stealing, recording etc.

\section{Conclusions}

The Analysis of the history of media education in Polish educational system has shown that Polish schools still need media education, which is encapsulated in three slogans: learning about, through and for media (Dylak, 1997). It is also difficult not to agree with Piotr Drzewiecki who perceives media education as "seemingly an integral element of educating an advanced society; at the same time it takes up the issue of how all interpersonal forms of communication do function" (Drzewiecki, 2010a).

In relation to the proposed changes in the core curriculum, various groups trying to exert pressure, and discussions in different ministries, the issue of media education in public school system still seems to be an open matter. That is precisely why the comments of Mirosław Filiciak are so on point - since the European Commission's directive on media education is not able to force MEN to commit to actively implementing the media topics in schools, the only thing that remains are guerrilla-type measures, acted outside of the mainstream (Filiciak, 2008).

Teachers' positive attitudes towards media in the current study have a special significance given the limitations characterizing the current status of ICT in Polish schools: insufficient computer resources and teachers' low level of digital competence.

One of the main barriers to technology implementation to Polish schools is the lack of clear goals of media education and mismatch between ICT and the existing curricula and the class-time frame. It follows that placing digital media in schools is not enough for attaining educational change. The introduction of ICT into education requires equal innovativeness in other aspects of education. Both policymakers and teachers share this responsibility.

Other barriers reported in this study were teachers' low level of access to school digital equipment, which may have played a role in teachers' modest digital competence so essential to media future use.

\section{Bibliography}

Baylor, A. \& Ritchie, D. (2002). What factors facilitate teacher skill, teacher morale, and perceived student learning in technology-using classrooms? Computers \& Education, 39(1), pp. 395-414.

Boroń, P. (2010). Edukacja medialna w Polsce XXI wieku ze szczególnym uwzględnieniem prac KRRiT $w$ latach 2007-2010. Available at: http://www.ktime.up.krakow.pl/ref2010/boron.pdf [12.03.2017].

Drzewiecki, P. (2010a). Edukacja medialna w nowej podstawie programowej kształcenia ogólnego. Biuletyn Edukacji Medialnej, nr 1. 
Drzewiecki, P. (2010b). MEDIA AKTYWNI. Dlaczego i jak uczyć edukacji medialnej? Otwock - Warszawa. 188 p. ISBN 978-83-940638-3-2

Dylak, S. (1997). Edukacja medialna w szkole. O mediach, przez media, dla mediów. [in:] W. Strykowski (Ed.), Media a edukacja: Materiaty konferencyjne I Konferencji Media a Edukacja. Poznań, Wydawnictwo eMPI², 480 p. ISBN 83-86421-61-4.

Dyrektywa 2007/65/WE Parlamentu Europejskiego i Rady z dnia 11 grudnia 2007 r. zmieniająca Dyrektywę 89/552/EWG Parlamentu Europejskiego i Rady z dnia 3.10.1989 r. w sprawie koordynacji niektórych przepisów ustawowych, wykonawczych i administracyjnych państw członkowskich dotyczących wykonywania telewizyjnej działalności nadawczej, Dz.U. UE L 332 z 18.12.2007.

Edukacja medialna w KRRiT, Available at: http://www.krrit.gov.pl/drogowskazmedialny/edukacja-medialna-w-krrit/ [2.03.2017].

Filiciak, M. (2008) MEN i edukacja medialna, czyli pudrowanie trupa, Kultura 2.0. Available at: http://kultura20.blog.polityka.pl/?p=654 [2.03.2017].

Godzic, W. (2000). Uczyć do mediów czy rozumieć media? [in:] J. Detka (Ed.), Pedagogika mediów. Materiały Konferencji Naukowej. Kielce, 14 kwietnia 2000 roku. Kielce, Wydaw. AŚ. 100 p. ISBN 8371331363.

Kersaint, G., Horton, B., Stohl, H., \& Garofalo, J. (2003). Technology beliefs and practices of mathematics education faculty. Journal of Technology and Teacher Education, 11(4), pp. 549-577.

Koohang, A. A. (1989). A study of the attitudes toward computers: anxiety, confidence, liking, and perception of usefulness. Journal of Research on Computing in Education, 22(2), pp. 137-150.

Krumsvik, R. (2008). Situated learning and teachers' digital competence, Education \& Information Technologies, 13, pp. 279- 290.

Lipszyc, J. (Ed.) (2012). Cyfrowa Przyszłość. Edukacja medialna i informacyjna w Polsce. Warszawa: Fundacja Nowoczesna Polska. Available at: http://nowoczesnapolska.org.pl/ V_[2.04.2017].

Long-term National Development Strategy. Poland 2030. The third wave of modernity. (Dlugookresowa Strategia Rozwoju Kraju. Polska 2013. Trzecia fala nowoczesności) (2013), Warszawa: The Ministry of Administration and Digitization.

Nowakowska-Buryła, I. (2003). Postawy dzieci wobec mediów. Edukacja Medialna, 1.

Siemieniecki, B. (2002). Edukacja humanistyczna i komputery. [in:] J. Gajda, S. Juszczyk, B. Siemieniecki, K. Wenta (Ed.), Edukacja medialna. Toruń, Wydawnictwo Adam Marszałek. 408 p. ISBN 83-7322-031-3.

Social Capital Development Strategy and Poland 2020 (2013), Uchwała Nr 61 Rady Ministrów z dnia 26 marca 2013 r. w sprawie przyjęcia „Strategii Rozwoju Kapitału Społecznego 2020" M.P. 2013 poz. 378.

ICT competency standards for teachers (2008). Implementation Guidelines version 1.0. UK: UNESCO. Available at: http://unesdoc.unesco.org/images/0015/001562/156209E.pdf [10.02.2017].

Strykowski, W. (1997). Media w edukacji: od nowych technik nauczania do pedagogiki i edukacji medialnej, [in:] W. Strykowski (Ed.), Media a edukacja: Materiaty konferencyjne I Konferencji Media a Edukacja. Poznań, Wydawnictwo eMPI², 480 p. ISBN 83-8642161-4. 
Szymanek, V. (Ed.). (2013) Information society in numbers (Społeczeństwo informacyjne w liczbach), Warszawa: The Ministry of Administration and Digitalization. ISSN 20827687.

The Ordinance of the Ministry of National Education (Rozporządzenie Ministra Edukacji Narodowej z dnia 23 grudnia 2008 r. w sprawie podstawy programowej wychowania przedszkolnego oraz kształcenia ogólnego w poszczególnych typach szkół), Dz. U. nr 4, Poz. 17). Available

at: http://www.dn.uj.edu.pl/documents/1333504/4915309/23.12.2008_rozp_MEN_podstawa _programowa?version $=1.0 \& \mathrm{t}=1352211869420$ [14.02.2017].

Ustawa o systemie oświaty z dnia 7 września 1991, Dz.U. 1991 nr 95 poz. 425. 